\title{
CHARACTERISTICS OF HELLP SYNDROME IN SEVERE PREECLAMPSIA PATIENTS IN DR. SOETOMO HOSPITAL SURABAYA
}

\author{
Warih Angesti $\mathbf{P}^{1}$, Ernawati ${ }^{2}$, Dwi Susanti ${ }^{3}$ \\ ${ }^{1}$ Medical Doctor Study Program, ${ }^{2}$ Department of Obstetric and Gynaecology, \\ ${ }^{3}$ Department of Public Health, Faculty of Medicine, Universitas Airlangga
}

\begin{abstract}
ABSTRAK
Hemolysis, elevated liver enzyme, low platelet count (HELLP) syndrome merupakan komplikasi yang menyertai preeklampsia berat yang merupakan salah satu penyebab utama kematian ibu hamil di Indonesia. Tujuan dari penelitian ini untuk mengetahui prevalensi, karakteristik, dan keadaan pasca bersalin pasien HELLPs yang melahirkan di Dr. Soetomo Hospital pada Juli 2012-Juni 2013. Penelitian ini adalah deskriptif observasional dengan rancangan studi cross sectional. Populasi yang diteliti adalah pasien preeklampsia berat yang melahirkan di Dr. Soetomo Hospital dan memiliki data rekam medis yang lengkap pada periode Juli 2012Juni 2013. Pengambilan sampel dilakukan dengan total sampling. HELLP syndrome menyertai 7\% pasien preeklampsia berat. Ratarata usia pasien HELLPs adalah 30,2 (19-43), sedangkan pada non-HELLPs adalah 30,8 (17-46). Kehamilan pertama dan kedua banyak didapatkan pada pasien HELLPs. Rata-rata usia gestasi saat persalinan pasien HELLPs adalah 33-34 minggu. Pasien HELLPs dan non-HELLPs sebagian besar melaksanakan persalinan cesarean section. Tidak ada kematian maternal tercatat pada kelompok HELLPs. Bayi kelompok HELLPs sebanyak 25\% lahir mati. Rata-rata berat badan lahir (BBL) kelompok HELLPs sebesar 1994,4 g. Nilai Apgar $\geq 7$ didapatkan pada 33,3\% bayi kelompok HELLPs. Sebagai simpulan, kehamilan pertama dan kedua banyak didapatkan pada HELLPs, dan kehamilan pertama pada non-HELLPs. Rata-rata usia gestasi saat persalinan lebih rendah pada kelompok HELLPs. Angka kejadian lahir mati pada pasien HELLPs lebih tinggi. Bayi kelompok HELLPs memiliki rata-rata BBL lebih rendah. Bayi dengan nilai Apgar $\geq 7$ lebih tinggi pada kelompok non-HELLPs.(FMI 2015;51:272-276)
\end{abstract}

Kata kunci: HELLP syndrome, prevalensi, usia ibu, usia gestasi, paritas, cara persalinan, post-partum outcome, berat badan lahir, nilai Apgar

\begin{abstract}
Hemolysis, elevated liver enzyme, and low platelet count syndrome (HELLPS) is complication following severe preeclampsia which is one of the three leading causes of maternal mortality in Indonesia. The purpose of this study was to understand the prevalence, characteristics, and post-partum outcome of HELLPs patients who deliver in Dr. Soetomo Hospital in July 2012-June 2013. This study was observational-descriptive, cross sectional study. The population observed was the severe preeclampsia patients who deliver in Dr. Soetomo Hospital and have complete medical data in July 2012-June 2013. study subject taken by total sampling. HELLPs follow the 7\% of severe preeclampsia patients. The maternal average age of HELLPs group was 30.2 (19-43), while in nonHELLPs was 30.8 (17-46). Most HELLPs patients were in the first and second pregnancy. The average of gestational age at labor in HELLPs was 33-34 weeks. Both in HELLPs and non-HELLPs most performed Cesarean Section delivery. No post-partum maternal mortality found in HELLPs, but 25\% had stillbirth. The average of birth weight in HELLPs was $1994.4 \mathrm{~g}$. First minute Apgar score $\geq 7$ was $33.3 \%$ in HELLPs group. In conclusion, Most HELLPs patients were in the first and second pregnancy, while non-HELLPs were in first pregnancy. The average of gestational age at labor was lower in HELLPs group. Neonates mortality were higher in HELLPs group. The average of birth weight was lower in HELLPs group. First minute Apgar score $\geq 7$ was higher in non-HELLP group.(FMI 2015;51:272-276)
\end{abstract}

Keywords: HELLP syndrome, prevalence, maternal age, gestational age, parity, mode of delivery, post-partum outcome, birth weight, Apgar score

Correspondence: Warih Angesti P, Villa Puncak Tidar V-146, Malang, East Java. Phone: 081357979489.

Email: warihangesti@gmail.com

\section{INTRODUCTION}

Preeclampsia is complication following pregnancy, signed by hypertension and proteinuria, and differed from pregnancy induced hypertension (PIH). Preeclampsia occurred in $2-8 \%$ pregnancy and increase maternal mortality and morbidity. According to The
National Institute of Health (2010), preeclampsia signed by systolic pressure $>140 \mathrm{mmHg}$, dyastolic pressure $>90 \mathrm{mmHg}$, and proteinuria >300 $\mathrm{mg}$. Severe preeclampsia diagnosed if systolic pressure $>160 \mathrm{mmHg}$, dyastolic pressure $>110 \mathrm{mmHg}$, proteinuria $\geq 5000 \mathrm{mg}$, oliguria $(<500 \mathrm{ml}$ in 24 hours $)$, cerebral and visual disturbances, epigastric pain, liver dysfunction, lung 
oedema, cyanosis, thrombocytopenia, or found intrauterine growth restriction.

Hemolysis, elevated liver enzyme, and low platelet count syndrome (HELLPs) is complication following severe preeclampsia. HELLP syndrome occur in $0.2-$ $0.6 \%$ from all pregnancies, whether $10-12 \%$ in severe preeclampsia (Benedetto et al 2011). Hanumanthappa (2011) states possible patophysiology that might underlie HELLP syndrome. Vascular repair mechanism deficiency added vasospasme will develop into endothelial dysfunction. This dysfuction will promote platelet aggregation and fibrin activation. These aggregation and activation then leads into manifestation occurrence. Platelet over-aggregation leads to thrombocytopenia, while fibrin activation cause hemolysis of the erythrocyte passing through the dysfunctioned endothelial. The elevation of liver enzyme caused by ischemic of the liver. The three main manifestations of HELLP syndrome caused by endothelial dysfunction.

Satpathy et al (2009) made diagnostic criteria for each HELLPs manifestations. Hemolysis, diagnosed if at least have 2 of these 4 criterias: abnormal peripheral blood smear (found schistocyte, burr cells, and echinocyte), increased indirect bilirubin $(>1.2 \mathrm{mg} / \mathrm{dl})$, decreased blood haptoglobin, and decreased in hemoglobin - not by haemorrhage. Elevated liver enzymes marked by increased in transaminase (AST and ALT $>70 \mathrm{IU} / \mathrm{L}$ or twice from the normal), lactate dehydrogenase $(>600 \mathrm{IU} / \mathrm{L})$, and increased of total bilirubin $(>1.2 \mathrm{mg} / \mathrm{dl})$. Thrombocytopenia defined as platelet count $<150,000$.

HELLP syndrome had been classified, and one of the common used was Mississippi classification that divide HELLPs into three classes. The difference of each class were in transmaminase and platelet count while LDH $>600 \mathrm{IU} / \mathrm{L}$ in all classes. Class I marked by AST or ALT $>70$ IU/L and platelet count $<50,000 / \mu \mathrm{L}$. Class II marked by AST atau ALT $>70$ IU/L, and platelet count $50,000-100,000 / \mu \mathrm{L}$, while in class III AST or ALT $>40$ IU/L, and platelet count 100,000-150,000/ $\mu \mathrm{L}$ (Hanumanthappa 2011).

Suportive treatment could be given to HELLPs patients such as anti-convulsion and anti-hypertension (Padden 1999). Conservative management done in HELLP patients with gestational age <34 weeks, while pregnancy termination done in patients with gestational age >34 weeks. Corticosteroid could be given in gestational age 24-34 weeks to promote lung maturity (Haram et al 2009).

\section{MATERIALS AND METHODS}

This study was an observational descriptive, with cross sectional study. The population observed was severe preeclampsia patients who deliver in Dr. Soetomo Hospital in July 2012-June 2013. The subject of study taken by total sampling, using study materials such as medical records. The inclusion criteria were maternal age, gestational age, parity, mode of delivery, birth weight, and first minute Apgar score. study instrument used was observational sheet to collect data.

\section{RESULTS}

This study using severe preeclampsia patients medical records who deliver in Dr. Soetomo Hospital in July 2012-June 2013. The total of severe preeclampsia patients was 461 patients, but only 352 samples which pass the inclusion criterias. Twenty four (7\%) patients had HELLP syndrome complication.

Table 1 shows that the average of maternal age in HELLPs group was 30.2 (19-43), while in non-HELLPs group was 30.8 (17-46). Most patients of HELLPs group were in the first and second pregnancy, while non-HELLPs most in the first pregnancy. HELLPs group averagely performed labor in 33-34 weeks of gestational age, while non-HELLPs performed in 36-37 weeks. Most patients from both both group HELLPs and non-HELLPs performed cesarean section delivery. This is showed at table 2 .

Post-partum outcome of the mother and neonates showed in table 3. No mortality noted in HELLPs group. Twenty five percents neonates from HELLPs group were stillbirth. The average of birth weight of the living neonates from HELLPs group was $1994.4 \mathrm{~g}$, while in non-HELLPs was $2656.3 \mathrm{~g}$. Thirthy three percents of HELLPs babies had Apgar score $\geq 7$ and $70.4 \%$ for non-HELLPs group. 
Table 1. Characteristics of HELLPs and non-HELLPs in Dr. Soetomo Hospital in July 2012-June 2013

\begin{tabular}{|c|c|c|c|c|}
\hline \multirow{2}{*}{ Subject characteristics } & \multicolumn{4}{|c|}{ HELLP syndrome } \\
\hline & $(+)$ & & $(-)$ & \\
\hline Maternal age & & & & \\
\hline $\begin{array}{l}<20 \\
20-<35 \\
\geq 35\end{array}$ & $\begin{array}{l}2 \\
16 \\
6\end{array}$ & $\begin{array}{l}(8.3) \\
(66.7) \\
(25)\end{array}$ & $\begin{array}{l}15 \\
207 \\
106\end{array}$ & $\begin{array}{l}(4.6) \\
(63.1) \\
(32.3)\end{array}$ \\
\hline $\begin{array}{l}\text { Parity } \\
\text { Primigravid }\left(1^{\text {st }} \text { pregnancy) }\right. \\
\text { Multigravid }\left(2^{\text {nd }} \text { to } 5^{\text {th }} \text { pregnancy) }\right. \\
\text { Grandemultigravid (more than } 5^{\text {th }} \text { pregnancy) }\end{array}$ & $\begin{array}{l}8 \\
14 \\
2\end{array}$ & $\begin{array}{l}(33.3) \\
(58.3) \\
(8.3)\end{array}$ & $\begin{array}{l}113 \\
202 \\
13\end{array}$ & $\begin{array}{l}(34.5) \\
(61.6) \\
(4)\end{array}$ \\
\hline $\begin{array}{l}\text { Gestational age } \\
<34 \text { weeks (very preterm) } \\
\geq 34-<37 \text { weeks (moderate preterm) } \\
\geq 37 \text { weeks }(\text { aterm) }\end{array}$ & $\begin{array}{l}10 \\
6 \\
8\end{array}$ & $\begin{array}{l}(41.7) \\
(25) \\
(33.3)\end{array}$ & $\begin{array}{l}71 \\
58 \\
199 \\
\end{array}$ & $\begin{array}{l}(21.6) \\
(17.7) \\
(60.7)\end{array}$ \\
\hline
\end{tabular}

Table 2. Mode of delivery in HELLPs and non-HELLPs group in Dr. Soetomo Hospital in July 2012-June 2013

\begin{tabular}{lcccc}
\hline \multirow{2}{*}{ Mode of delivery } & \multicolumn{4}{c}{ HELLP syndrome } \\
\cline { 2 - 5 } & \multicolumn{3}{c}{$(+)$} & $(-)$ \\
\hline Cesarean section $(\mathrm{CS})$ & 15 & $(62.5)$ & 159 & $(48.5)$ \\
Spontaneous & 7 & $(29.2)$ & 152 & $(46.3)$ \\
Extraction & 1 & $(4.2)$ & 17 & $(5.2)$ \\
Abortion & 1 & $(4.2)$ & - & - \\
\hline Total & 24 & $(100)$ & 328 & $(100)$ \\
\hline
\end{tabular}

Table 3. Post-partum outcome in patients HELLPs and non-HELLPs group in Dr. Soetomo Hospital July 2012-June 2013

\begin{tabular}{lllll}
\hline \multirow{2}{*}{ Post-partum Outcome } & \multicolumn{5}{c}{ HELLP syndrome } \\
\cline { 2 - 4 } & \multicolumn{1}{c}{$(+)$} & & \\
Maternal outcome & & & & \\
Alive & 24 & $(100)$ & 327 & $(99.7)$ \\
Dead & - & - & 1 & $(0.3)$ \\
\hline Neonatal outcome & & & & \\
Alive & 18 & $(75)$ & 321 & $(94.1)$ \\
Stillbirth & 6 & $(25)$ & 20 & $(5.9)$ \\
\hline BBL & & & & \\
$<1000$ (extremely low birth weight) & 2 & $(11.1)$ & 4 & $(1.2)$ \\
1000-<2500 (low birth weight) & 11 & $(61.1)$ & 109 & $(34.0)$ \\
2500 (normal birth weight) & 5 & $(27.8)$ & 208 & $(64.8)$ \\
\hline Apgar score 1' & & & & \\
$0-3$ & 6 & $(33.3)$ & 50 & $(15.6)$ \\
4-6 & 6 & $(33.3)$ & 45 & $(14.0)$ \\
$7-10$ & 6 & $(33.3)$ & 226 & $(70.4)$ \\
\hline
\end{tabular}

\section{DISCUSSION}

In this study, HELLP syndrome occur in $7 \%$ of severe preeclampsia patients. Khumsat et al (2008) had a study also in severe preeclampsia patients and had a result that HELLP syndrome occurs in $12.5 \%$. The prevalence of
HELLP syndrome in this study was lower than in Khumsat, could be caused by the period of time for taking samples no long enough, this study take the samples in one year while Khumsat's in 2 years. This lower result also could be caused by the difference of samples-taking location. 
Audibert et al (1996) and Martin \& Conrad (2000) in their study found that maternal age in HELLPs commonly older that the non.HELLPs. In this study, the average of maternal age in HELLPs group was 30.2 (1943), while in non-HELLPs group was 30.8 (17-46). This was because the composition of maternal deliver in Dr. Soetomo Hospital most were 30 years old. Had been reported by Ahmed et al (2007) that $62.5 \%$ patients in HELLP syndrome were multigravid, and $71.7 \%$ patients in non-HELLPs were primigravid. In this study most of HELLPs patients were in the first and second pregnancy, while non-HELLPs patients were in the first pregnancy. No exact explanation for this result.

Commonly (64\%), babies from HELLPs delivered in 32 weeks of gestational age (Roelofsen et al 2003). Supported by Singhal et al (2004), the average of gestational age when labor performed was 32,6 in HELLPs group. In this study, HELLPs group had the average 33-34 weeks of gestational age when labor performed, while in non-HELLPs group the average was 36-37 weeks of gestational age. The explanation would be the longer the pregnancy maintained, the higher risk of mortality of the mother, even would decrease the morbidity of the babies. Portis et al (1997) states that the management of HELLP syndrome was principally to optimalize maternal condition with preventing perinatal risk that might occur as the result of premature birth. Theoritically, HELLP syndrome cause the damage of microvascular endothelial that then promote the activation of intravascular platelet. This activation then promote thromboxan A secretion and serotonin that will lead to vasopsasm, aggregation, and agglutination process that will further worsen the endothelial damage, and so on. This process will only be cured by pregnancy termination (Sibai et al 1993).

Wang et al (2010) in their study found that from 59 patients from HELLPs group that were observed, $15.4 \%$ had intauterine fetal death (IUFD). In this study, 20.8\% patients of HELLPs group had IUFD, while in nonHELLPs group there was $4.6 \%$. This might be caused by the endothelial damage in severe preeclampsia worsen by hemolysis as one of three manifestations in HELLP syndrome, causing the lack of nutrition and oxygen transport through the placenta.

Osmanagaoglu (2006) observed 36 patients of HELLPs, $75 \%$ among them performed cesarean section (CS) delivery. In this study found that most of HELLPs patients (64\%) performed CS delivery, so did nonHELLPs group with $46.16 \%$ for CS delivery. This caused by the need of emergency CS delivery associate with maternal and fetal condition, or because the history of CS delivery before. The mode of delivery chosen according to cervical status, history of delivery, and maternal-fetal condition (Baxter et al 2004). Emergency labor indicated if maternal blood pressure >160/110 $\mathrm{mmHg}$ and wouldn't get better with anti-hypertensive, worsen symptoms, decreasing renal function, severe ascites, placental abruption, oligouria, lung oedema, and eclampsia (Gul et al 2005). No agreement yet made about the best delivery time and mode for HELLPs case (Haram et al 2009).

HELLP syndrome cause $0-24 \%$ of maternal mortality (Weinstein 1982, Sibai et al 1993). In the opinion of Turgut et al (2010), HELLPs patients experience the increasing of morbidity and mortality. Liu et al (2006) stated that the maternal mortality rate between the HELLPs and non-HELLPs group show no difference. In this study, no mortality found in the HELLPs group, while one patient in non-HELLPs. This indicate an aggressive management of HELLP syndrome so that mother had decreased risk of mortality.

The neonates born in this study were 365 babies. Stillbirth found in $25 \%$ percents of neonates born from HELLPs group, while $6.2 \%$ found in non-HELLPs. This could be caused by the management of HELLP syndrome principally to optimize maternal condition and prevents mother from death, so that termination performed if pregnancy had been in the 34 weeks of gestation, or if the maternal condition worsen. While the perinatal morbidity and mortality rate associate with the gestational age when labor performed (Abramovici et al 1999).

In the study of Erkilinc \& Eyi (2013) that observed neonatal outcome in HELLP syndrome, show that $19 \%$ neonates born with birth weight $<1500 \mathrm{~g}, 41.8 \%$ with $1500-<2500 \mathrm{~g}$, and $39.2 \%$ with $\geq 2500 \mathrm{~g}$. In this study, neonates born from HELPs had the average of birth weight $1994.4 \mathrm{~g}$, while non-HELLPs group had 2656.3 g. This could be explained because in coomon, neonates from HELLPs born in the age of gestation <34 weeks, that leads to low birth weight. The outcome of neonates associates with the occurrence of placental abruption, intrauterine asphyxia, and prematurity. In Khumsat et al (2008) study, the first minute Apgar score $\geq 7$ was $50 \%$ in HELLPs group. In this study, the first minute Apgar score $\geq 7$ was $33.3 \%$ in HELLPs group, while $70.4 \%$ in non-HELLPs group. The prematurity would once again explain this, because in the gestational age <34 weeks, the maturity of lung not yet completed, that would lead to low Apgar score.

\section{CONCLUSION}

The HELLPs group average maternal age was 30.2 (1943), while in non-HELLPs was 30.8 (17-46). Most 
HELLPs patients were in the first and second pregnancy, while non-HELLPs were in first pregnancy. The average of gestational age at labor was lower in HELLPs group. Neonates mortality were higher in HELLPs group. The average of birth weight was lower in HELLPs group. First minute Apgar score $\geq 7$ was higher in non-HELLP group.

\section{REFERENCES}

Abramovici D, Friedman SA, Mercer BM, Audibert F, Kao L, Sibai BM (1999). Neonatal outcome in severe preeclampsia at 24 to 36 weeks' gestation: does the HELLP (hemolysis, elevated liver enzymes, and low platelet count) syndrome matter?. American Journal of Obstetric and Gynecology 180, 221-225

Ahmed FA, et al (2007). HELLP syndrome, a clinical variant of pre-eclampsia. ANNALS 13, 158-161

Audibert F, Friedman SA, Frangieh AY, Sibai BM (1996). Clinical utility of strict diagnostic criteria for the HELLP (hemolysis, elevated liver enzyme, and low platelets) syndrome. American Journal of Obstetrics and Gynecology 175, 460-464

Baxter JK, Weinstein L (2004). HELLP syndrome: the state of the art. Obstetrics and Gynecological Survey $59,838-845$

Benedetto C, Marozio L, Tancredi A, Picardo E, Nardolillo P, Tavella AM, Salton L (2011). Biochemistry of HELLP syndrome. Adv Clin Chem 53, 85-104

Erkilinc S and Eyi EGY (2013). Adolescent pregnancies complicated by HELLP syndrome: clinical experience of 26 cases. The Journal of GynecologyObstetrics and Neonatology 10, 1643-1646

Gul A, Cebeci A, Aslan H, Polat I, Ozdemir A, Ceylan Y (2005). Perinatal outcomes in severe preeclampsiaeclampsia with and without HELLP syndrome. Gynecol Obstet Invest 59, 113-118

Hanumanthappa M (2011). Clinical study of HELLP syndrome in preeclampsia and eclampsia. Dissertation. Mysore Medical College and study Institute, Mysore. Available from http://119.82.96. 198:8080/jspui/bitstream/123456789/4943/1/Hanuma nthappa\%20M.pdf. Accessed June 28, 2013

Haram K, Svendsen E, Abildgaard U (2009). The HELLP syndrome: clinical issues and management. A review. BMC Pregnancy and Childbirth 9, 8

Khumsat R, Wongwananurak T, Boriboonhirunsarn D (2008). Incidence and Risk Factors of HELLP Syndrome in Thai Pregnant Women with Severe Preeclampsia. Thai Journal of Obtetrics and Gynaecology $16,192-198$
Liu CM, Chang SD, Cheng PJ, Chao AS (2006). Comparisons of maternal and perinatal outcomes in Taiwanese women with complete and partial HELLP syndrome and women with severe preeclampsia without HELLP. Journal of Obstetric and Gynaecology study 32, 550-558

Martin D and Conrad KP (2000). Expression of endothelial nitric oxide synthase by extravillous trophoblast cells in the human placenta. Placenta 21, 23-31

The National Institute of Health (2010). Diagnosis and management of preeclampsia: an update. Available from http://www.ncbi.nlm.nih.gov/pmc/articles/PMC 2990902/ Accessed June 22, 2013.

Osmanagaoglu MA, Osmanagaoglu S, Ulusoy H, Bozkaya H (2006). Maternal outcome in HELLP syndrome requiring intensive care and management in a Turkish hospital. Sao Paulo Medical Journal 124, 85-89

Padden MO (1999). HELLP syndrome: recognition and perinatal management. American Family Physician 60, 829-836

Portis R, Jacobs MA, Skerman JH, Skerman EB (1997). HELLP syndrome (hemolysis, elevated liver enzymes, and low platelets) patophysiology and anesthetic considerations. AANA Journal 65, 37-47

Roelofsen AC, van Pampus MG, Aarnoudse JG (2003). The HELLP-syndrome; maternal-fetal outcome and follow up infants. Journal Perinatal Medicine 31, 201208

Satpathy HK, Satpathy C, Frey D (2009). Review article: HELLP syndrome. J Obstet Gynecol India 59, 30-40

Sibai BM, Ramadan MK, Usta I, Salama M, Mercer BM, Friedman SA (1993). Maternal mrbidity and mortality in 442 pregnancies with hemolysis, elevated liver enzymes, and low platelets (HELLP syndrome). American Journal of Obstetrics and Gynecology 169, 1000-1006

Singhal N, Amin HJ, Pollard JK, Tough SC, Johnston DW, Clark DJ, Sauve R (2004). Maternal haemolysis, elevated liver enzymes and low platelets syndrome: perinatal and neurodevelopmental neonatal outcomes for infants weighing less than $1250 \mathrm{~g}$. Journal of Paediatric and Child Health 40, 121-126

Wang YQ, Wang J, Ye RH, Zhao YY (2010). Investigation of diagnosis and treatment of hemolysiselevated liver enzymes-low platelet counts (HELLP) syndrome: clinical analysis of 59 cases. Chin Med J (Engl) 123, 1273-1277

Weinstein L (1982). Syndrome of hemolysis, elevated liver enzymes, and low platelet count: a severe consequence of hypertension in pregnancy. American Journal of Obstetrics and Gynecology 142, 159-167 